\title{
Viability of Gypsum Composites with Addition of Glass Waste for Applications in Construction
}

\author{
Paola Villoria Sáez ${ }^{1}$; Mercedes del Río Merino²; Evangelina Atanes Sánchez \\ Jaime Santa Cruz Astorqui ${ }^{4}$; and César Porras-Amores ${ }^{5}$
}

\begin{abstract}
The design of greener materials is of great interest to develop eco-efficient construction systems, causing less environmental impact and following circular economy criteria. Accordingly, the current study aimed to analyze the viability to incorporate glass wastefrom construction and demolition-in gypsum composites, promoting a circular economy in the building construction sector. Gypsum-based composites were formulated using different percentages and particle sizes of glass waste, and samples were prepared. These samples were tested in the laboratory, and the following characteristics were determined: dry density, surface hardness, mechanical strength, water absorption by capillarity, and thermal conductivity. Analysis comparing these composites to reference gypsum without additions showed that it is viable to prepare gypsum composites with the addition of glass waste to reduce water absorption by capillarity, improve mechanical strength, and increase surface hardness. All composites comply with the minimum requirements set by regulations. Therefore, these composites can be applied in the manufacturing of gypsum prefabricated elements or as interior coatings requiring special surface hardness, improved water behavior, and mechanical strength properties.
\end{abstract}

Author keywords: Construction waste; Recycling; Gypsum; Building; Innovation; Eco-gypsum.

\section{Introduction}

Currently, 461 million tons of construction and demolition waste (CDW) are generated per year in the European Union, representing approximately $30 \%$ of total waste generated (Eurostat 2017). The proper management of this waste constitutes one of the main pillars of the Europe 2020 Strategy regarding the use of resources, based on the three Rs of a circular economy (reduce, reuse, recycle) (European Commission 2010). Nonetheless, efforts should be focused on turning construction waste into a business opportunity, and the construction industry must adopt the objective of promoting the use of recycled materials (Adams et al. 2017).

According to previous research, the main waste categories generated in building construction are concrete, mortars, and

${ }^{1}$ Assistant Professor, Escuela Técnica Superior de Edificación, TEMA Research Group, Universidad Politécnica de Madrid, Avenida Juan de Herrera, 6 Madrid 28040, Spain (corresponding author). Email: paola .villoria@upm.es

${ }^{2}$ Full Professor, Escuela Técnica Superior de Edificación, TEMA Research Group, Universidad Politécnica de Madrid, Avenida Juan de Herrera, 6 Madrid 28040, Spain.

${ }^{3}$ Professor, Escuela Técnica Superior de Ingeniería y Diseño Industrial, Mechanical \& Chemical and Design Industrial Engineering Dept., Universidad Politécnica de Madrid, Ronda de Valencia 3, 28012 Madrid, Spain.

${ }^{4}$ Professor, Escuela Técnica Superior de Edificación, TEMA Research Group, Universidad Politécnica de Madrid, Avenida Juan de Herrera, 6 Madrid 28040, Spain.

${ }^{5}$ Assistant Professor, Escuela Técnica Superior de Edificación, TEMA Research Group, Universidad Politécnica de Madrid, Avenida Juan de Herrera, 6 Madrid 28040, Spain. ceramics (del Río Merino et al. 2018). These wastes have found extensive use as recycled aggregates for concrete and mortars (Matias et al. 2014; Ozbakkaloglu et al. 2018; Saiz Martínez et al. 2016). However, in Spain, the amount of other CDWs has increased in recent years due to an increase of building rehabilitation and retrofitting to improve energy efficiency as a consequence of RD 314/2006, Spain's Technical Building Code (Spanish Government 2006; Villoria Sáez et al. 2018). In particular, glass waste has increased because replacing windows is a common action performed by homeowners due to its simplicity and efficiency in saving energy.

Glass is a transparent material manufactured by melting several inorganic raw compounds at very high temperature, followed by fast controlled cooling, resulting in an isotropic, noncrystallized, hard, stable, and inert material. Glasses are classified based on major composition and the additives used in the manufacturing process. Soda-lime glass, from containers and flat glass, makes up more than $80 \mathrm{wt} \%$ of waste glass (Memon et al. 2013; Shi and Zheng 2007). The main raw material is silica; the other most common raw materials are sodium carbonate $\left(\mathrm{Na}_{2} \mathrm{CO}_{3}\right)$, limestone $\left(\mathrm{CaCO}_{3}\right)$, and dolomite $\left[\mathrm{CaMg}\left(\mathrm{CO}_{3}\right)_{2}\right]$. The resulting glass is composed of oxides originating in the thermal decomposition of the raw materials.

The glass industry uses huge amounts of natural resources as raw materials and is one of the most energy-consuming industries due to the high temperatures needed for melting. However, the recycling of glass as an alternative raw material for manufacturing new construction materials has not had the same success as other aggregates. Although glass waste recovery and recycling are extensive because of the efficiency of remelting glass, there are several difficulties that arise when considering the overall recycling process (Lim 2014). These difficulties have led to a search for alternative recycling options-for example, aggregates for building compounds.

Several studies have analyzed the behavior of different building compounds, where traditional construction raw materials are 
Table 1. Studies on the incorporation of glass waste in gypsum or cement matrix

\begin{tabular}{|c|c|c|c|c|}
\hline Reference & Matrix & Waste type & $\begin{array}{c}\text { Glass } \\
\text { content }(\%)\end{array}$ & Results \\
\hline Marco et al. (2012) & Cement mortars & Glass powder $(0.011-0.016 \mathrm{~mm})$ & $70-90$ & $\begin{array}{l}\text { Strength increased with both more fine-grained } \\
\text { glass powder used as binder and more cement }\end{array}$ \\
\hline Ganjian et al. (2015) & Concrete/paving blocks & $\begin{array}{l}\text { Granulated blast furnace, cement } \\
\text { dust and crushed glass }(4.0-6.0 \mathrm{~mm})\end{array}$ & 53 & $\begin{array}{l}\text { Best mix achieved with } 6-\mathrm{mm} \text { replacement: } \\
\text { excellent water absorption, freeze/thaw, and } \\
\text { density }\end{array}$ \\
\hline $\begin{array}{l}\text { Bhandari and Tajne } \\
\text { (2013) }\end{array}$ & Cement mortar/blocks & $\begin{array}{l}\text { Window glass waste: } \\
\text { fine }(0.6-1.18 \mathrm{~mm}) \\
\text { coarse }(1.18-4.75 \mathrm{~mm})\end{array}$ & $10-30$ & $\begin{array}{l}\text { Compressive strength decreased as glass waste } \\
\text { increased; coarse particles resulted in greater } \\
\text { decrease than fine particles; less water absorbed in } \\
\text { samples containing waste glass compared with } \\
\text { control samples }\end{array}$ \\
\hline Lim (2014) & Concrete & $\begin{array}{l}\text { Waste glass as fine-powder } \\
\text { aggregates in concrete }(<4.75 \mathrm{~mm})\end{array}$ & $10-25$ & $\begin{array}{l}\text { Concrete mix with } 10 \% \text { fine aggregate replaced } \\
\text { with waste glass maintained compressive strength } \\
\text { similar to that of reference }\end{array}$ \\
\hline $\begin{array}{l}\text { Topcu and Canbaz } \\
\text { (2004) }\end{array}$ & Concrete & $\begin{array}{l}\text { Waste glass from bottles } \\
(4-6.0 \mathrm{~mm})\end{array}$ & $15-60$ & $\begin{array}{l}\text { Compressive strength decreased with increasing } \\
\text { glass waste; with } 60 \% \text { coarse aggregate in concrete } \\
\text { mixture replaced with waste glass, tensile strength } \\
\text { decreased } 37 \%\end{array}$ \\
\hline Park et al. (2004) & Concrete & $\begin{array}{l}\text { Waste glass from bottles: } \\
\text { fine aggregate } \leq 5 \mathrm{~mm}\end{array}$ & $30-70$ & $\begin{array}{l}\text { Compressive strength decreased with increasing } \\
\text { glass waste; with } 30 \% \text { fine aggregate replaced with } \\
\text { waste glass, tensile strength decreased } 5 \%\end{array}$ \\
\hline Tounchuen et al. (2014) & Gypsum & $\begin{array}{l}\text { Automotive print-screened glass } \\
\text { waste powder }\end{array}$ & $0-20$ & Strength and water insolubility improved \\
\hline
\end{tabular}

replaced by alternative materials with lower environmental impact. Today, in addition to cement mortar composites, gypsum composites are of crucial importance as finishing materials and are being increasingly used in building construction because they are abundant in nature and have positive technical and ecological properties (Gencel et al. 2016). In particular, the production temperature of gypsum, in comparison with cement, is much lower and thus energy consumption and the $\mathrm{CO}_{2}$ emissions released during manufacturing are highly reduced compared with the manufacture of cement-based materials. Many studies have explored the behavior of gypsum composites incorporating different construction and demolition wastes, thus helping to close the cycle of the waste generated in building construction and promoting circular economy criteria (Gutiérrez González et al. 2012; Morales Conde et al. 2016; San-Antonio-González et al. 2016; Vidales Barriguete et al. 2018).

Regarding glass waste recycling, much research has focused on incorporating glass in different proportions and sizes for the production of cement mortars (Bhandari and Tajne 2013; Marco et al. 2012; Park et al. 2004), concrete (Du and Tan 2014; Topcu and Canbaz 2004), and ceramic compounds (Kazmi et al. 2017) (Table 1). Several literature reviews on the addition of glass waste in cement composites have been published (e.g., Jani and Hogland 2014; Mohajerani et al. 2017). In particular, Jani and Hogland (2014) reported studies using up to $75 \%$ glass waste aggregate of two particle sizes: coarse grain $(2.36-0.60 \mathrm{~mm})$ and fine powder $(0.30-0.15 \mathrm{~mm})$. This literature review revealed that there is no clear information on how the amount of glass waste added and particle size affect the mechanical properties of concrete (Jani and Hogland 2014; Mohajerani et al. 2017).

Despite much research on using glass waste in cement mortars and other composites, little has been found on incorporating glass in gypsum (Shi and Zheng 2007). Only one study investigated the addition of up to $20 \%$ glass waste powder-from the automotive industry-in gypsum (Tounchuen et al. 2014). Its results showed that glass powder improved the resistance and water insolubility of the gypsum composite. For such reasons, the behavior of gypsum incorporating higher percentages of glass waste is of great interest.
This study attempted to further analyze the feasibility of incorporating glass waste in gypsum, increasing the amount added by previous researchers and considering two particle sizes. Gypsum composites containing glass waste can be used as interior coatings or for the production of gypsum-based prefabricated elements needing higher superficial hardness and mechanical behavior. Furthermore, incorporating these fillers in a gypsum matrix reduces the amount of raw material used for its manufacture and represents an improvement over gypsums without additions.

\section{Materials and Experimental Plan}

The materials used is this study were

- Coarse gypsum, referred to here as YG, consisting of calcium sulfate hemihydrate and supplied by Saint Gobain Placo (Madrid, Spain).

- Colorless glass waste, obtained from window glass at a building site, crushed with a Micro-Deval crusher (Ibertest, Madrid, Spain) and sieved to obtain coarse-grain (1-2 mm) and finepowder $(\leq 125 \mu \mathrm{m})$ particles referred to as $\mathrm{G}$ and $\mathrm{F}$, respectively (Fig. 1).

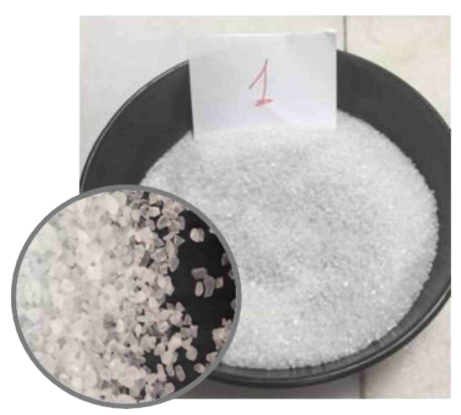

(a)

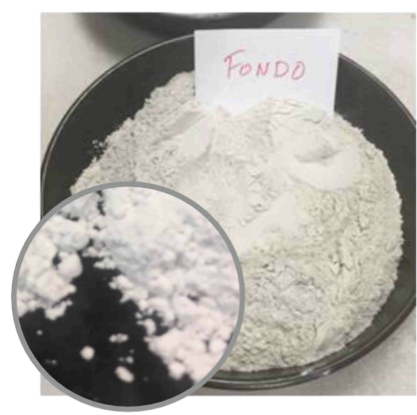

(b)
Fig. 1. Glass waste: (a) coarse grain; and (b) fine powder. 
An experimental plan was developed to analyze the properties of the different gypsum composites. Twelve series of gypsum samples incorporating different percentages of glass waste were prepared with a water/gypsum ratio of 0.8 (Table 2 ). The experimental plan unfolded in four phases.

In Phase 1, both coarse-grain and fine-powder glass waste was progressively added to gypsum powder. The resulting mixture was combined with water and mixed in a planetary mixer for 2 min, according to European Standard EN 13279-2 (CEN 2006), for homogenization. Three $4 \times 4 \times 16-\mathrm{cm}^{3}$ samples were formed which were kept for 7 days in a laboratory atmosphere (temperature of $23 \pm 2{ }^{\circ} \mathrm{C}$ and relative humidity of $37 \pm 1 \%$ ) and stored for $24 \mathrm{~h}$ in a Stove IEP Control (IEP Control, Madrid, Spain) model 150 stove at $60 \pm 2{ }^{\circ} \mathrm{C}$ before testing.

In Phase 2, the samples were tested for density and Shore C superficial hardness as well as compressive and flexural strength. For each test, the mean value achieved with the three samples was calculated and the results were compared not only with the reference sample - to calculate the percentage of deviation - but also with the minimum values established by EN 13279-1 (CEN 2009) for regular gypsums (Type B1) (Table 3 ). The relationship to estimate the compressive and flexural strength of a gypsum composite once its density is known was also explored by analyzing the results obtained for each sample with different linear regressions, using Microsoft Excel, to obtain the data trend equation. The models' coefficients of determination $\left(R^{2}\right)$ were also determined.

In Phase 3, the composites performing better in the second phase were selected and further tested for water absorption by capillarity and thermal behavior. Once the measurements were

Table 2. Composition of gypsum samples

\begin{tabular}{lcl}
\hline Series & Composites & \multicolumn{1}{c}{ Composition } \\
\hline 1 & $\mathrm{REF}$ & Reference sample: no glass waste added \\
2 & $\mathrm{YG}+20 \% \mathrm{~F}$ & Different wt $\%$ addition of fine-powder \\
3 & $\mathrm{YG}+30 \% \mathrm{~F}$ & glass waste $(<0.125 \mathrm{~mm})$ \\
4 & $\mathrm{YG}+40 \% \mathrm{~F}$ & \\
5 & $\mathrm{YG}+50 \% \mathrm{~F}$ & \\
6 & $\mathrm{YG}+70 \% \mathrm{~F}$ & \\
7 & $\mathrm{YG}+90 \% \mathrm{~F}$ & \\
8 & $\mathrm{YG}+100 \% \mathrm{~F}$ & \\
9 & $\mathrm{YG}+20 \% \mathrm{G}$ & Different wt $\%$ addition of coarse-grain \\
10 & $\mathrm{YG}+50 \% \mathrm{G}$ & glass waste $(1-2 \mathrm{~mm})$ \\
11 & $\mathrm{YG}+75 \% \mathrm{G}$ & \\
12 & $\mathrm{YG}+100 \% \mathrm{G}$ & \\
\hline
\end{tabular}

Table 3. Specifications for gypsum in construction

\begin{tabular}{lccc}
\hline Type & $\begin{array}{c}\text { Flexural } \\
\text { strength } \\
\left(\mathrm{N} / \mathrm{mm}^{2}\right)\end{array}$ & $\begin{array}{c}\text { Compressive } \\
\text { strength } \\
\left(\mathrm{N} / \mathrm{mm}^{2}\right)\end{array}$ & $\begin{array}{c}\text { Superficial } \\
\text { hardness } \\
\left(\mathrm{N} / \mathrm{mm}^{2}\right)\end{array}$ \\
\hline $\begin{array}{l}\text { B1-Gypsum for construction }{ }^{\mathrm{a}} \\
\text { B2-Gypsum mortar }\end{array}$ & $\geq 1$ & - \\
B3-Gypsum mortar with lime ${ }^{\mathrm{c}}$ & & & \\
B4-Lightweight gypsum & & \\
B5-Lightweight gypsum mortar & & \\
B6-Lightweight gypsum & & $\geq 6$ & $\geq 2.5$ \\
mortar with lime & & \\
B7-High-hardness gypsum & $\geq 2$ & \\
for construction & & \\
\hline Source: Data from CEN (2009). & & \\
${ }^{\mathrm{a} A m o u n t}$ of gypsum $\geq 50 \%$. & & \\
${ }^{\mathrm{b}}$ Amount of gypsum <50\%. \\
${ }^{\mathrm{c}}$ Amount of gypsum depends on whether gypsum alone $(>50 \%)$ or gypsum \\
mortar (<50\%); in all cases, lime content is $>5 \%$.
\end{tabular}

taken, the average values were obtained and compared with the reference sample. Also, a Dino-Lite microscope was used to observe how the waste was distributed and how it bonded with the gypsum composites.

In Phase 4, the reduction in consumed raw material (gypsum) was analyzed in selected composites and compared with the reference sample. This analysis involved the quantities of each material (gypsum, glass, and water) to produce the three samples as well as their weight after demolding.

\section{Experimental Procedures}

\section{Glass Waste Characterization}

The chemical composition of the glass waste was analyzed by $\mathrm{X}$-ray fluorescence on a Philips Magix (Philips, Spain) machine. Using a Quantachrome SPY-3 stereopycnometer, the real density was determined by measuring the volume of helium [Air Liquide (Madrid, Spain) ALPHAGAZ 99.999\%] evacuated by a known mass of sample. The loose bulk density of the glass samples was determined by pouring the solid into a $50-\mathrm{ml}$ test tube and dividing the mass by the volume of bed. It was calculated as the mean value of three measurements for each sample. Loose bulk density was used to measure the macroscopic volume of particles (including internal pores) plus the volume of voids between them. In addition, X-ray diffraction patterns were obtained in a Siemens Krystalloflex D5000 (Siemens, Madrid, Spain) unit using a graphite monochromator with $\mathrm{Cu} \mathrm{K} \alpha$ (1.2). The samples were scanned over the range $5^{\circ} \leq 2 \Theta \leq 100^{\circ}$ every $0.04^{\circ}$, 1 s per step.

\section{Mechanical Characterization}

Samples were mechanically and physically tested according to dry density, Shore C surface hardness, and flexural and compressive strength using the Ibertest Autotest 200/10-SW (Ibertest, Madrid, Spain) 200/10-SW test frame according to EN 13279-2 and UNE 102042 (AENOR 2014) standards.

\section{Water Absorption by Capillarity and Thermal Conductivity}

Water absorption by capillarity was tested following the methodology developed by Vidales Barriguete et al. (2018) and Del Río Merino et al. (2018), which follows European Standard EN 459-2 (CEN 2011). Samples were weighed and placed vertically in a container with a bottom grid and containing $10 \mathrm{~mm}$ of water. Capillarity absorption was measured after $10 \mathrm{~min}$. Samples were weighed before and after the test, and the amount of absorbed water was calculated using the difference between these measurements. Finally, the water capillarity coefficient was obtained using Eq. (1) (Juhász et al. 2014)

$$
k=\frac{m}{A \sqrt{t}}=\frac{m}{0.04 \times 0.04 \mathrm{~m}^{2} \sqrt{10 \mathrm{~min}}}
$$

where $m=$ volume of $=$ absorbed water $(\mathrm{kg}) ; A=$ absorbing surface $\left(0.04 \times 0.04 \mathrm{~m}^{2}\right)$; and $t=$ time $(10 \mathrm{~min})$.

Thermal conductivity was obtained by means of heat transfer at steady-state using a thermal conductivity analyzer [Model C-Therm TCi (C-THERM Technologies, Madrid, Spain)]. Samples were dried in a stove at $60 \pm 2^{\circ} \mathrm{C}$ for $24 \mathrm{~h}$ and left in a desiccator before testing in the laboratory. A thermal grease was applied on the surface of the sensor and the sample was placed on top. Thermal conductivity was measured in at least six different areas of the sample. 
Measurements were taken on all sides except for the upper side, which had a rough surface.

\section{Results and Discussion}

\section{Glass Waste Characterization}

The chemical composition of the flat glass used is provided in Table 4. The results obtained follow the conclusions reached in the literature for soda-lime glass, which is typically used in the manufacture of flat glass (Jani and Hogland 2014). The main component is silicon oxide for network forming, organized in a threedimensional (3D) structure of $\mathrm{SiO}_{4}$ tetrahedra; in minor quantities calcium, sodium, and magnesium oxides constitute the network modifiers.

The real density obtained for the glass waste was $2.7 \mathrm{~g} / \mathrm{cm}^{3}$; the loose bulk densities achieved for coarse-grain and fine-powder glass waste were 1.40 and $1.21 \mathrm{~g} / \mathrm{cm}^{3}$, respectively. Results from the X-ray diffraction test, shown in Fig. 2, reveal the low crystallinity of the sample and the presence of the characteristic band of the amorphous silica (Carsana et al. 2014; Galvão et al. 2015). The amorphous character of glass is due to the disordered 3D network of silicon tethahedra formed during fast cooling in the manufacturing process (Shi and Zheng 2007).

\section{Mechanical Characterization}

According to the results obtained from the density test, all composites increased in density compared with the reference sample. For this reason, according to EN 13279-1, gypsum composites containing glass waste additions cannot be considered lightweight (Type B4) because all densities surpass $1 \mathrm{~g} / \mathrm{cm}^{3}$. Moreover, results for composites containing the same percentage of glass waste but different particle size (coarse grain or fine powder) showed higher densities with coarse-grain particles compared with fine powder

Table 4. Chemical composition of fine-powder glass waste obtained by $\mathrm{XRF}$

\begin{tabular}{lc}
\hline Oxide & wt $\%$ \\
\hline $\mathrm{SiO}_{2}$ & 72.8 \\
$\mathrm{CaO}$ & 19.4 \\
$\mathrm{Na} 2 \mathrm{O}$ & 3.43 \\
$\mathrm{MgO}$ & 2.12 \\
$\mathrm{Fe}_{2} \mathrm{O}_{3}$ & 0.852 \\
$\mathrm{Al}_{2} \mathrm{O}_{3}$ & 0.485 \\
$\mathrm{SO}_{3}$ & 0.338 \\
$\mathrm{TiO}_{2}$ & 0.193 \\
\hline
\end{tabular}

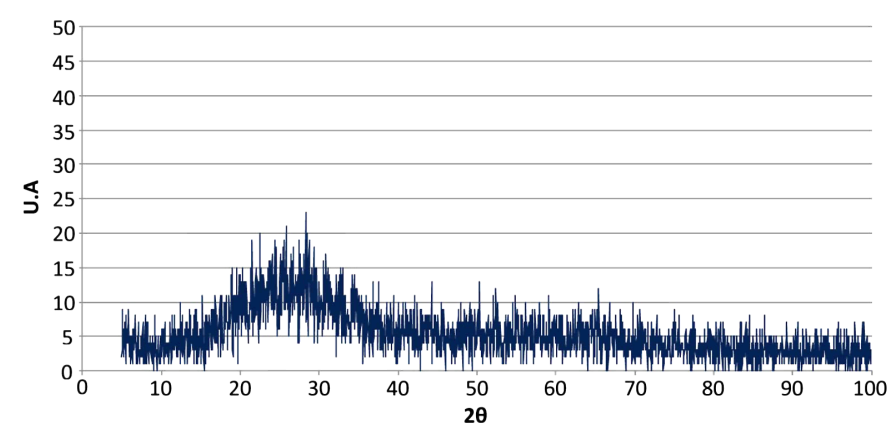

Fig. 2. Diffractogram of fine-powder glass waste.
(Fig. 3). In particular, the density of the samples containing $100 \%$ fine-powder or coarse-grain glass increased $39.7 \%$ and $48.75 \%$, respectively, compared with the reference sample.

When comparing the densities obtained with glass waste in this study with those achieved in other studies with other CDWs in gypsum, it is seen that the densities obtained here are similar to the ones obtained with ceramic waste [del Río Merino et al. (2018)]. Del Río Merino et al. (2018) incorporated ceramic waste with a particle size of 1-2 mm in gypsum and achieved $1.25 \mathrm{~g} / \mathrm{cm}^{3}$ in composites containing $50 \%$ ceramic waste over the weight of the gypsum.

Figs. 4 and 5 show the flexural and compressive strength values obtained for each composite. Fig. 4 shows that those containing fine-powder glass waste achieve better flexural strength values as the percentage of glass increases. However, this trend stops when more than $70 \%$ fine-powder glass waste is added; at $90 \%$ and $100 \%$, flexural strength values slightly decrease although they are still above the reference value. In contrast, flexural strength values decrease when coarse-grain glass aggregates are added, reaching up to a $14 \%$ decrease compared with the reference value (gypsum containing $75 \%$ coarse-grain glass waste). Experimental results from different studies of cement composites agree that flexural strength decreases with increasing coarse-grain glass waste (Du and Tan 2014; Jani and Hogland 2014).

According to the compressive strength results shown in Fig. 5, it is observed that, generally, a higher percentage of fine-powder glass waste results in greater compressive strength-in this study, increasing resistance up to $60 \%$ compared with the reference sample.

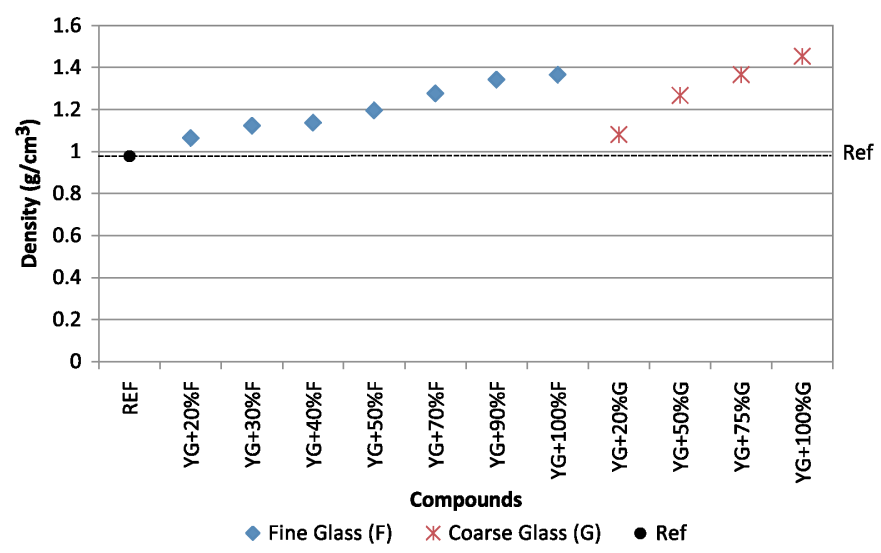

Fig. 3. Mean density results obtained for the series analyzed.

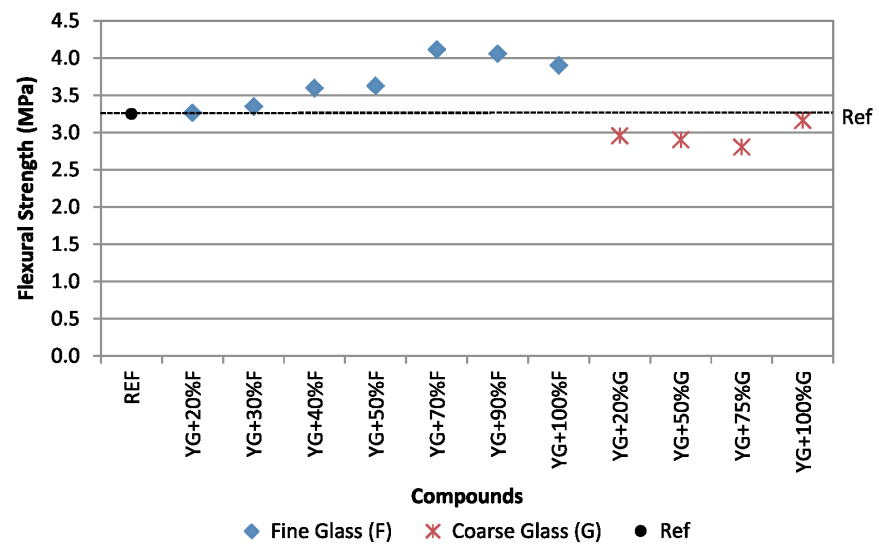

Fig. 4. Mean flexural strength obtained for the series analyzed. 


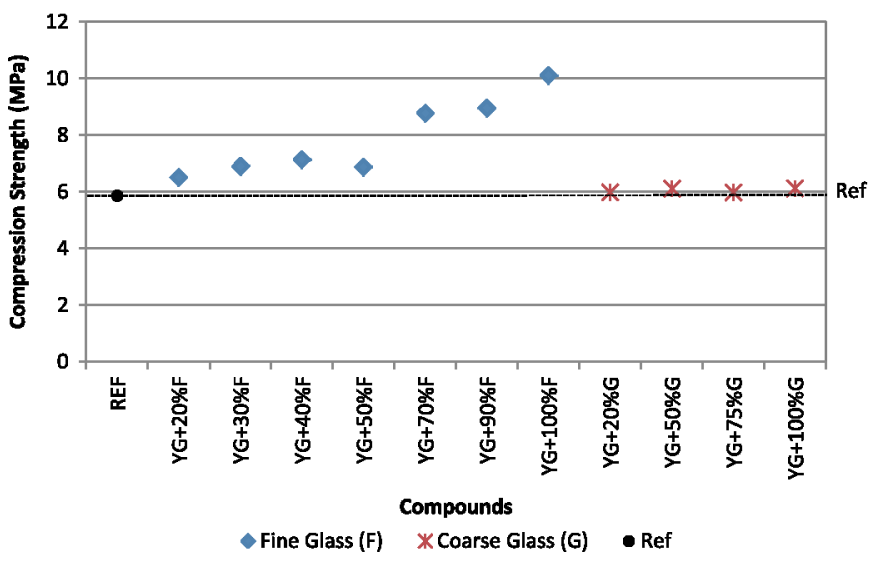

Fig. 5. Mean compressive strength obtained for the series analyzed.

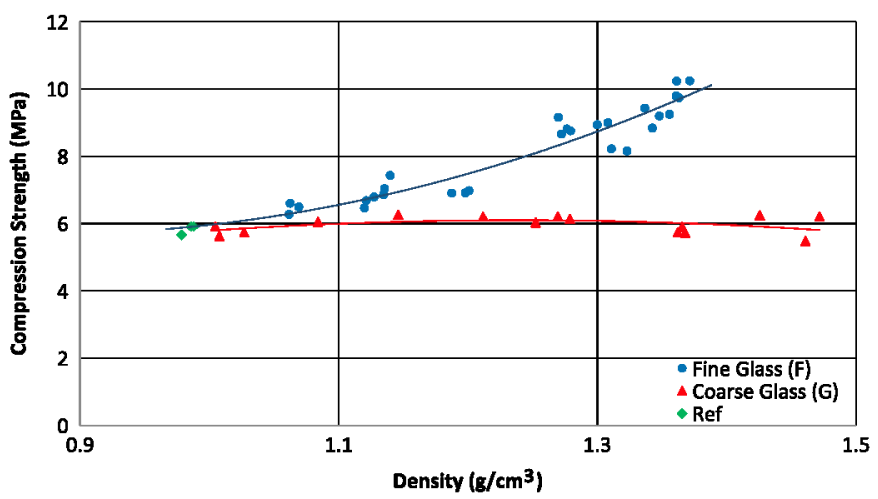

Fig. 6. Relationship between compressive strength and density obtained for each sample.

An increase in compressive strength was also found when up to $20 \%$ fine-powder glass waste was added to concrete (Batayneh et al. 2007). However, coarse-grain glass waste led to compressive strength values similar to the reference value. Lower compressive strength was also found by Topcu and Canbaz (2004) in cement mortars incorporating coarse-grain glass waste aggregates, due to the aggregates' poor shape, which caused a decrease in adhesive strength between the aggregates and the gypsum (Park et al. 2004).

In general, the results obtained for mechanical strength were better when small particle sizes were incorporated. These results are in agreement with conclusions reached by other studies on cement mortar composites and glass waste (Jani and Hogland 2014; Mohajerani et al. 2017). Therefore, particle size of the glass waste used is an important factor influencing the mechanical behavior of a gypsum composite.

Figs. 6 and 7 show the relationship between density and mechanical strength for each sample. It is observed that coarsegrain glass waste composites perform similarly to the reference sample in all cases, despite having higher densities. In contrast, only compounds with fine-powder glass follow a clear trend, increasing resistance as density increases. In particular, an increase up to $23.5 \%$ in flexural strength and around $60 \%$ in compressive strength is observed in samples containing $100 \%$ fine-powder glass waste.

Equations describing the relationship between density and mechanical strength for composites containing coarse-grain and fine-powder glass waste were explored, but in general adjustment with the data was too low to be accepted $\left(R^{2}<0.4\right)$, especially

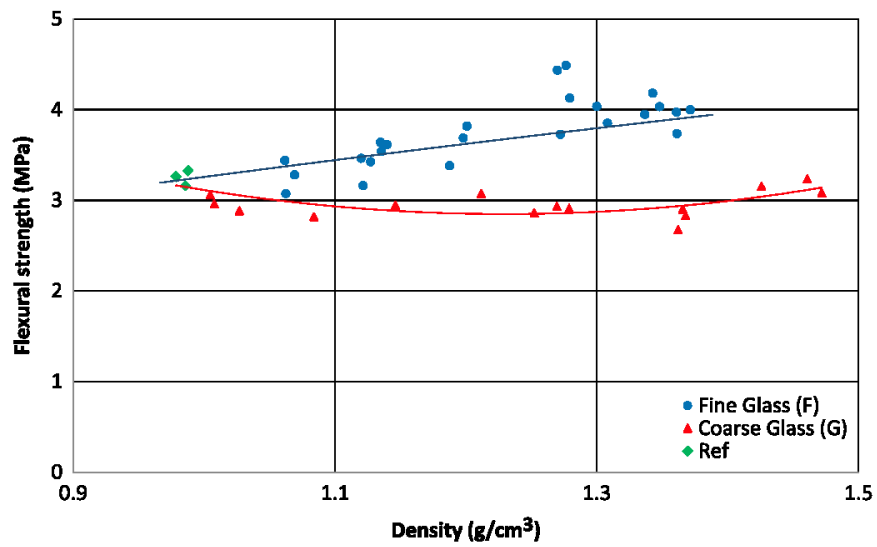

Fig. 7. Relationship between flexural strength and density obtained for each sample.

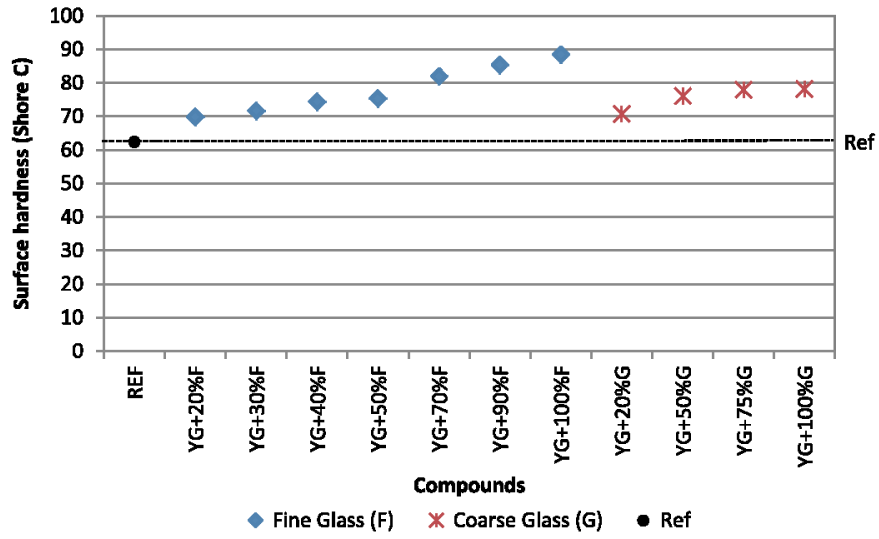

Fig. 8. Mean superficial hardness obtained for the series analyzed.

for composites with coarse-grain glass waste. However, a good adjustment was found for the polynomial equation describing the relationship between compressive strength and density for composites containing fine-powder glass waste [Eq. (2) and Fig. 6]

$$
C=16.458 \rho^{2}-28.606 \rho+18.109\left(R^{2}=0.921\right)
$$

where $C=$ composite compressive strength (MPa); and $\rho=$ composite density $\left(\mathrm{g} / \mathrm{cm}^{3}\right)$.

Results for Shore $\mathrm{C}$ hardness are shown in Fig. 8. In this case, all values exceed the reference value, reaching $41.7 \%$ when $100 \%$ with fine-powder glass and $25 \%$ with the same percentage of coarse-grain glass.

The results obtained in the mechanical tests show that all gypsum composites containing glass waste comply with the minimum values set by regulation for standard gypsums (Type B1). However, they also reveal that some composites comply with the values set by Standard RP 35.04 (AENOR 2009) for high-hardness gypsums (Type B7):

- Superficial hardness $\geq 75$ Shore C

- Compressive strength $\geq 6 \mathrm{MPa}$

- Flexural strength $\geq 2 \mathrm{MPa}$

- Thermal conductivity coefficient $=0.34 \mathrm{~W} / \mathrm{mK}$

In general, the analyzed gypsum composites comply with minimum flexural strength (2 MPa) and compressive strength (6 MPa) standards for high-hardness gypsums (especially compounds containing fine-powder glass). Furthermore, composites containing more than $40 \%$ fine-powder glass comply with regulations 
Table 5. Results for water absorption by capillarity

\begin{tabular}{lccc}
\hline Composite & $\begin{array}{c}\text { Water } \\
\text { absorption } \\
(\mathrm{mm})\end{array}$ & $\begin{array}{c}\text { Absorbed } \\
\text { water } \\
(\mathrm{g})\end{array}$ & $\begin{array}{c}\text { Capillarity } \\
\text { coefficient } \\
{\left[\mathrm{kg} /\left(\mathrm{m}^{2} / \mathrm{min}^{0.5}\right)\right]^{\mathrm{a}}}\end{array}$ \\
\hline Reference & 74.00 & 50.60 & 10.00 \\
YG + 50\%F & 36.33 & 36.83 & 7.28 \\
YG + 70\%F & 36.27 & 33.07 & 6.54 \\
YG + 100\%F & 32.83 & 29.83 & 5.90 \\
\hline
\end{tabular}

${ }^{\mathrm{a} C}$ Capillarity coefficient calculated using Eq. (1).

Table 6. Results for thermal behavior

\begin{tabular}{lc}
\hline Composite & $\begin{array}{c}\text { Thermal } \\
\text { conductivity } \\
\lambda(\mathrm{W} / \mathrm{mK})\end{array}$ \\
\hline Reference & 0.35 \\
YG $+50 \% \mathrm{~F}$ & 0.27 \\
YG $+70 \% \mathrm{~F}$ & 0.28 \\
YG $+100 \% \mathrm{~F}$ & 0.31 \\
\hline
\end{tabular}
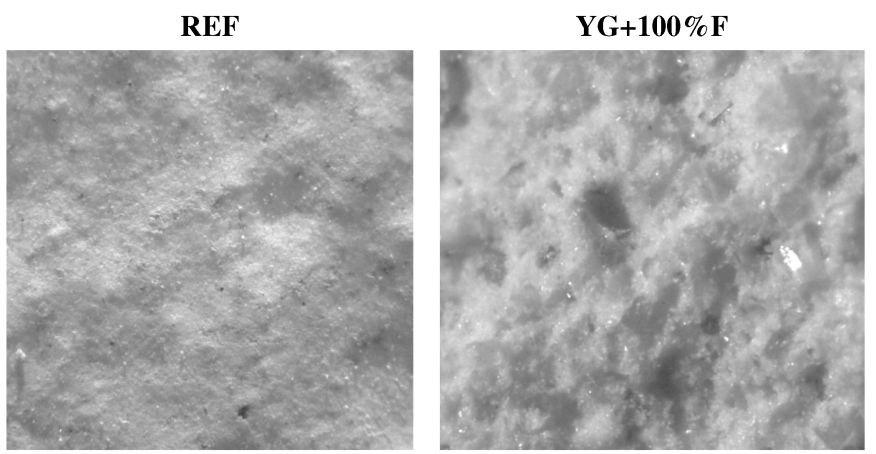

Fig. 9. Microscopic images $(50 \times)$ of the reference sample and a gypsum-based composite. for high-hardness gypsums, reaching values above 75 Shore C. Also, all densities are similar to those published by del Río Merino et al. (2018) for high-hardness gypsums.

\section{Water Absorption by Capillarity and Thermal Conductivity}

Three composites containing fine-powder glass were chosen due to the good results obtained in the mechanical tests: $\mathrm{YG}+50 \% \mathrm{~F}$, $\mathrm{YG}+70 \% \mathrm{~F}$, and $\mathrm{YG}+100 \% \mathrm{~F}$. These composites can be applied in continuous coatings or prefabricated elements for interior partitions needing higher hardness, due to their good properties of superficial hardness and mechanical strength.

Tables 5 and 6 provide results for thermal conductivity and water absorption by capillarity for selected composites containing $50 \%, 70 \%$, and $100 \%$ fine-powder glass. In addition to the three selected composites, the reference gypsum (without additions) was tested for comparison It was found that adding fine-powder glass reduced water absorption by capillarity in the gypsum reference without additions (Table 5). In particular, the water absorption and capillarity coefficient can be reduced around $44.4 \%$ and $59 \%$, respectively, with compounds containing $100 \%$ fine-powder glass.

According to the results provided in Table 6 , the thermal conductivity coefficients of the gypsum composites are similar to that of the reference sample, achieving about $0.3 \mathrm{~W} / \mathrm{mK}$ for all composites tested.

Finally, Fig. 9 shows the reference sample and a gypsum-based composite containing glass powder. It is seen that the glass waste is well distributed and adheres to the gypsum matrix.

\section{Consumption of Raw Material}

One of the main aims of this study was to provide a way to reduce the amount of natural resources consumed during the manufacture of gypsums composites. For this reason, the amount of gypsum that can be saved or reduced when glass waste is incorporated in composites was explored. Table 7 provides percentage reductions in raw material (i.e., gypsum) with respect to the reference gypsum

Table 7. Reduction in raw material consumption compared with reference sample

\begin{tabular}{|c|c|c|c|c|c|c|}
\hline \multirow[b]{2}{*}{ Composite } & \multirow[b]{2}{*}{ Material } & \multirow[b]{2}{*}{$\begin{array}{c}\text { Content } \\
\text { (wt } \%)\end{array}$} & \multicolumn{2}{|c|}{ Per sample } & \multirow[b]{2}{*}{$\begin{array}{l}\text { Quantity per } \\
\text { cubic meter }\end{array}$} & \multirow{2}{*}{$\begin{array}{l}\text { Reduction in raw } \\
\text { material per cubic } \\
\text { meter }(\mathrm{wt} \%)\end{array}$} \\
\hline & & & $\begin{array}{l}\text { Weight } \\
(\mathrm{g})\end{array}$ & $\begin{array}{l}\text { Volume } \\
\left(\mathrm{cm}^{3}\right)^{\mathrm{a}}\end{array}$ & & \\
\hline \multirow[t]{4}{*}{ Reference } & Gypsum & 55.56 & 218.8 & 84.17 & 0.32 & - \\
\hline & Water & 44.44 & 175.1 & 175.00 & 0.68 & \\
\hline & Fine-powder glass & 0.00 & 0.0 & 0.00 & 0.00 & \\
\hline & Total & 100.00 & 393.9 & 259.17 & 1.00 & \\
\hline \multirow[t]{4}{*}{$\mathrm{YG}+50 \% \mathrm{~F}$} & Gypsum & 43.48 & 185.9 & 71.49 & 0.28 & 13.5 \\
\hline & Water & 34.78 & 148.7 & 148.7 & 0.58 & \\
\hline & Fine-powder glass & 21.74 & 92.9 & 34.42 & 0.14 & \\
\hline & Total & 100.00 & 427.5 & 254.60 & 1.00 & \\
\hline \multirow[t]{4}{*}{$\mathrm{YG}+70 \% \mathrm{~F}$} & Gypsum & 40.00 & 175.8 & 67.62 & 0.27 & 18.0 \\
\hline & Water & 32.00 & 140.6 & 140.6 & 0.55 & \\
\hline & Fine-powder glass & 28.00 & 123.1 & 45.58 & 0.18 & \\
\hline & Total & 100.00 & 439.5 & 253.83 & 1.00 & \\
\hline \multirow[t]{4}{*}{$\mathrm{YG}+100 \% \mathrm{~F}$} & Gypsum & 35.71 & 163.5 & 62.90 & 0.25 & 23.8 \\
\hline & Water & 28.57 & 130.8 & 130.8 & 0.51 & \\
\hline & Fine-powder glass & 35.71 & 163.5 & 60.57 & 0.24 & \\
\hline & Total & 100.00 & 457.9 & 254.30 & 1.00 & \\
\hline
\end{tabular}

${ }^{2}$ Densities used to obtain volume: $2.7 \mathrm{~g} / \mathrm{cm}^{3}$ (glass waste); $2.6 \mathrm{~g} / \mathrm{cm}^{3}$ (gypsum); and $1 \mathrm{~g} / \mathrm{cm}^{3}$ (water). 
without additions. The results show that incorporating fine-powder glass, from $50 \%$ to $100 \%$ over the weight of gypsum, reduces the amount of gypsum raw material by $13.4 \%$ and $23.8 \%$, respectively. The workability of the selected composites varies depending on the amount of waste because the waste absorbs a small part of the mixing water, although it still mixes well. Therefore, the progressive addition of higher percentages of fine-powder glass waste requires greater water quantities to ensure the same consistency.

\section{Conclusions}

It is feasible to use glass waste as a substitute for gypsum as a way to encourage the generation of greener construction materials, which generally have lower costs and meet the principals of cleaner production. The addition of glass waste in a gypsum matrix has a noticeable effect on the physical and mechanical properties of the gypsums, improving mechanical and surface hardness compared with gypsums without additions. All gypsum composites analyzed in this study comply with current regulations. In particular, those containing over $40 \%$ fine-powder glass waste can be considered high-hardness gypsums, as they comply with the minimum specifications set by regulations for this gypsum type (Type B7).

Although all of the composites studied comply with minimum requirements, fine-powder glass waste is highly recommended because it provided better results in the tests performed. The gypsum composite containing $100 \%$ fine-powder glass (over the weight of the gypsum) improved compressive strength by around $60 \% \mathrm{com}-$ pared with the reference gypsum. Furthermore, fine-powder glass can increase surface hardness by around $40 \%$ compared with an increase of $25 \%$ obtained with coarse-grain glass waste. Also, the composite containing $100 \%$ fine-powder glass reduced the gypsum content by around $23 \%$ compared with the reference sample. Finally, fine-powder glass reduced water absorption by capillarity by up to $45 \%$.

A clear relationship was found between the density and compressive strength of gypsum composites containing fine-powder glass waste. An equation was determined aiming to estimate the compressive strength of the gypsum composite once its density was known. In contrast, composites containing coarse-grain glass waste kept mechanical resistance constant (similar to that of the reference) despite increasing the amount of glass and thus density.

Based on physical and mechanical properties, as well as the low environmental impact of gypsum composites with glass waste, it is worth mentioning that construction products may be produced from mixes containing up to $100 \%$ fine-powder glass waste. In particular, these gypsum composites can be used as coatings for interior partitions or for gypsum-based prefabricated elements (such as boards for false ceilings) needing high superficial hardness and better performance against water capillarity. In this way, the consumption of finite resources can be reduced. Also, the use of glass waste will reduce the amount of natural gypsum and thus the corresponding costs of extraction and preparation.

\section{Acknowledgments}

This research was supported by the Ministry of Economy and Competitiveness of the Spanish Government (Project reference number BIA2013-43061-R). The authors gratefully acknowledge the support of the Materials Laboratory staff at the School of Building Construction of the Universidad Politécnica de Madrid.

\section{References}

Adams, K., M. Osmani, T. Thorpe, and J. Thornback. 2017. "Circular economy in construction: Current awareness, challenges and enablers." Proc. Inst. Civ. Eng. Waste Resour. Manage. 170 (1): 15-24. https://doi .org/10.1680/jwarm.16.00011.

AENOR (Spanish Association for Standardisation and Certification). 2009. "Reglamento de producto que recoge las exigencias particulares de yesas de alta dureza" [Supplementary regulation of high hardness gypsum productsy. Reglamento de Producto 35.04. Madrid: AENOR.

AENOR (Spanish Association for Standardisation and Certification). 2014 Yesos de construcción. Otros métodos de ensayo" [Gypsum plasters. Other test methods]. UNE 102042. Madrid: AENOR.

Batayneh, M., I. Marie, and I. Asi. 2007. "Use of selected waste materials in concrete mixes." Waste Manage. 27 (12): 1870-1876. https://doi.org/10 $.1016 / \mathrm{j}$. wasman.2006.07.026.

Bhandari, P., and K. Tajne. 2013. "Use of waste glass in cement mortar." Int. J. Civ. Struct. Eng. 3 (4): 704. https://doi.org/10.6088/ijcser .201203013064 .

Carsana, M., M. Frassoni, and L. Bertolini. 2014. "Comparison of ground waste glass with other supplementary cementitious materials." Cem. Concr. Compos. 45 (Jan): 39-45. https://doi.org/10.1016/j.cemconcomp.2013 .09 .005 .

CEN (European Committee for Standardisation). 2006. Gypsum binders and gypsum plasters. Part 2: Test methods. EN 13279-2. Brussels: CEN.

CEN (European Committee for Standardisation). 2009. Gypsum binders and gypsum plasters. Part 1: Definitions and requirements. EN 13279-1. Brussels: CEN.

CEN (European Committee for Standardisation). 2011. Building lime. Part 2: Test methods. EN 459-2. Brussels: CEN.

del Río Merino, M., J. Santa Cruz Astorqui, P. Villoria Sáez, R. Santos Jiménez, and M. González Cortina. 2018. "Eco plaster mortars with addition of waste for high hardness coatings." Constr. Build. Mater. 158 (Jan): 649-656. https://doi.org/10.1016/j.conbuildmat.2017.10.037.

Du, H., and K. H. Tan. 2014. "Waste glass powder as cement replacement in concrete." J. Adv. Concr. Technol. 12 (11): 468-477. https://doi.org $/ 10.3151 /$ jact. 12.468 .

European Commission. 2010. Europe 2020: A strategy for smart, sustainable and inclusive growth: Communication from the commission. Brussels, Belgium: European Union.

Eurostat. 2017. "Eurostat statistics for waste flow generation 2014." Accessed February 15, 2018. http://epp.eurostat.ec.europa.eu/portal /page/portal/eurostat/home/.

Galvão, A., A. Farias, and J. Mendes. 2015. "Characterization of waste of soda-lime glass generated from lapping process to reuse as filler in composite materials as thermal insulation." Ceramica 61 (359): 367-373. https://doi.org/10.1590/0366-69132015613591987.

Ganjian, E., G. Jalull, and H. Sadeghi-Pouya. 2015. Using waste materials and by-products to produce concrete paving blocks. Constr. Build. Mater. 77: 270-275.

Gencel, O., J. J. del Coz Diaz, M. Sutcu, F. Koksal, F. P. Á. Rabanal, and G. Martínez-Barrera. 2016. "A novel lightweight gypsum composite with diatomite and polypropylene fibers." Constr. Build. Mater. 113 (Jun): 732-740. https://doi.org/10.1016/j.conbuildmat.2016.03.125.

Gutiérrez González, S., J. Gadea, A. Rodríguez, C. Junco, and V. Calderón. 2012. "Lightweight plaster materials with enhanced thermal properties made with polyurethane foam wastes." Constr. Build. Mater. 28 (1): 653-658. https://doi.org/10.1016/j.conbuildmat.2011.10.055. https:// doi.org/10.1016/j.conbuildmat.2011.10.055.

Jani, Y., and W. Hogland. 2014. "Waste glass in the production of cement and concrete-A review." J. Environ. Chem. Eng. 2 (3): 1767-1775. https://doi.org/10.1016/j.jece.2014.03.016.

Juhász, P., K. Kopecskó, and Á. Suhajda. 2014. "Analysis of capillary absorption properties of porous limestone material and its relation to the migration depth of bacteria in the absorbed biomineralizing compound." Periodica Polytechnica Civ. Eng. 58 (2): 113-120. https://doi .org/10.3311/PPci.7020.

Kazmi, S. M., S. Abbas, M. L. Nehdi, M. A. Saleem, and M. J. Munir. 2017. "Feasibility of using waste glass sludge in production of 
ecofriendly clay bricks." J. Mater. Civ. Eng. 29 (8): 04017056. https:// doi.org/10.1061/(ASCE)MT.1943-5533.0001928.

Lim, A. 2014. "The use of waste glass as a partial substitution for fine aggregate in concrete design." Ph.D. thesis, School of Engineering and IT, Charles Darwin Univ.

Marco, I., E. Carcfa, M. Mas, V. Alcaraz, and A. Luizaga. 2012. "Study of the compressive strength of mortars made with binders composite glass powder." Informes de la Construcción 64 (528): 529-536. https://doi .org/10.3989/ic.11.100.

Matias, G., P. Faria, and I. Torres. 2014. "Lime mortars with heat treated clays and ceramic waste: A review." Constr. Build. Mater. 73 (Dec): 125-136. https://doi.org/10.1016/j.conbuildmat.2014.09.028.

Memon, S. A., T. Y. Lo, and H. Cui. 2013. "Utilization of waste glass powder for latent heat storage application in buildings." Energy Build. 66 (Nov): 405-414. https://doi.org/10.1016/j.enbuild.2013.07.056.

Mohajerani, A., J. Vajna, T. H. H. Cheung, H. Kurmus, A. Arulrajah, and S. Horpibulsuk. 2017. "Practical recycling applications of crushed waste glass in construction materials: A review." Constr. Build. Mater. 156 (Dec): 443-467. https://doi.org/10.1016/j.conbuildmat.2017.09.005.

Morales Conde, M. J., C. Rodríguez Liñán, and M. A. Pedreño Rojas. 2016. "Physical and mechanical properties of wood-gypsum composites from demolition material in rehabilitation works." Constr. Build. Mater. 114 (Jul): 6-14. https://doi.org/10.1016/j.conbuildmat.2016.03.137.

Ozbakkaloglu, T., A. Gholampour, and T. Xie. 2018. "Mechanical and durability properties of recycled aggregate concrete: Effect of recycled aggregate properties and content." J. Mater. Civ. Eng. 30 (2): 04017275. https://doi.org/10.1061/(ASCE)MT.1943-5533.0002142.

Park, S. B., B. C. Lee, and J. H. Kim. 2004. "Studies on mechanical properties of concrete containing waste glass aggregate." Cem. Concr. Res. 34 (12): 2181-2189. https://doi.org/10.1016/j.cemconres.2004.02.006.

Saiz Martínez, P., M. González Cortina, F. Fernández Martínez, and A. Rodríguez Sánchez. 2016. "Comparative study of three types of fine recycled aggregates from construction and demolition waste (CDW), and their use in masonry mortar fabrication." J. Cleaner Prod. 118 (Apr): 162-169. https://doi.org/10.1016/j.jclepro.2016.01.059.

San-Antonio-González, A., M. D. R. Merino, C. V. Arrebola, and P. Villoria-Sáez. 2016. "Lightweight material made with gypsum and EPS waste with enhanced mechanical strength." J. Mater. Civ. Eng. 28 (2): 04015101. https://doi.org/10.1061/(ASCE)MT.1943-5533.0001382.

Shi, C., and K. Zheng. 2007. "A review on the use of waste glasses in the production of cement and concrete." Resour. Conserv. Recycl. 52 (2): 234-247. https://doi.org/10.1016/j.resconrec.2007.01.013.

Spanish Government. 2006. "de 17 de marzo, por el que se aprueba el Código Técnico de la Edificación" [Royal Decree 314/2006, of March 17, which approves the Technical Building Code]. RD 314/2006. Madrid: Ministerio de Vivienda, Construcción y Saneamiento.

Topcu, I. B., and M. Canbaz. 2004. "Properties of concrete containing waste glass." Cem. Concr. Res. 34 (2): 267-274. https://doi.org/10 .1016/j.cemconres.2003.07.003.

Tounchuen, K., W. Buggakupta, and W. Panpa. 2014. "Characteristics of automotive glass waste-containing gypsum bodies made from used plaster mould." In Vol. 608 of Key engineering materials, 91-96. Stafa-Zurich, Switzerland: Trans Tech Publications.

Vidales Barriguete, A., M. del Río Merino, E. Atanes Sánchez, C. Piña Ramírez, and C. Viñas Arrebola. 2018. "Analysis of the feasibility of the use of CDW as a low-environmental-impact aggregate in conglomerates." Constr. Build. Mater. 178 (Jul): 83-91. https://doi.org/10 .1016/j.conbuildmat.2018.05.011.

Villoria Sáez, P., J. Santa Cruz Astorqui, M. del Río Merino, M. d. P. Mercader Moyano, and A. Rodríguez Sánchez. 2018. "Estimation of construction and demolition waste in building energy efficiency retrofitting works of the vertical envelope." $J$. Cleaner Prod. 172 (Jan): 2978-2985. https://doi.org/10.1016/j.jclepro.2017.11.113. 